\title{
COMPARATIVE STUDY AMONG DIFFERENT DAIRY PRODUCTION SYSTEMS IN EGYPT
}

\author{
E. Ghoneim, S. El Kaschab, S. Omar and M.F. Omran \\ Animal Production, Dep. Fac. of Agric. Menoufia Univ. Egypt
}

Received: Jul. 30 , 2018

Accepted: Aug. 14, 2018

\begin{abstract}
The present study was carried out between October 2014 and September 2015 to characterize and evaluate 297 different cattle and buffalo dairy production systems which represents the most distributed diary systems in Egypt. The Systems included Commercial Systems (CS), Government commercial Systems (GS), Government Research Systems (GR), Traditional Landless system (TLL), Traditional mixed system (TMS) and Traditional intensive Systems (TIS).

Results showed that animal breeds had highly significant effect $(P<0.001)$ on all productive traits. Least squares means $\pm S D$ of total milk yield were $10613 \pm 2692 \mathrm{~kg}$, $2715 \pm 1697 \mathrm{~kg}, 1844 \pm 86 \mathrm{~kg}, 1629 \pm 637 \mathrm{~kg}, 1661 \pm 714 \mathrm{~kg}$ and $2603 \pm 733 \mathrm{~kg}$ for (CS), (GS), (GR), (TLL), (TMS) and (TIS), respectively. However, 4\% fat corrected milk yield (FCM) reached the value of 10136.32 $\pm 2571.29,2470.82 \pm 1544.36,2813.09 \pm 862.32$, 2858.44 \pm 1196.06, $2712.45 \pm 1270.82$ and $2901.17 \pm 853.08 \mathrm{~kg}$ for (CS), (GS), (GR), (TLL), (TMS) and (TIS), respectively.

Least squares means $\pm S D$ for average daily milk yield per head were $27.78 \pm 5.53,9.41 \pm$ $3.74,6.81 \pm 2.02,7.37 \pm 2.68,6.22 \pm 2.49 \mathrm{~kg}$ and $11.30 \pm 2.56 \mathrm{~kg}$ for (CS), (GS), (GR), (TLL), (TMS) and (TIS) respectively. The average of daily fat corrected milk per head were 26.14 $\pm 5.13,8.55 \pm 3.24,10.37 \pm 3.02,10.31 \pm 4.14,10.79 \pm 3.95$ and $12.24 \pm 4.25 \mathrm{~kg}$ for the same systems, respectively. This associated with lactation length (LL) of $387.77 \pm 98.39,289.50$ $\pm 140.76,271.04 \pm 92.21,222.59 \pm 36.22,266.15 \pm 30.96$ and $230.12 \pm 28.96$ days, respectively.

Reproductive traits such as calving interval (CI), service period (SP) and numbers of services per conception (NSPC) showed highly significant differences among the different systems. Least squares means $\pm S D$ of (CI) for (CS), (GS), (GR), (TLL), (TMS) and (TIS) systems were 438.30 $\pm 112.766,470.75 \pm 113.434,533.67 \pm 91.896,387.57 \pm 56.293$, $410.86 \pm 62.202$ and $423.75 \pm 53.817$ days, respectively. However, the least squares mean $\pm S D$ of $(S P)$ were $163.12 \pm 110.23,107.72 \pm 69.63,155.50 \pm 89.57,117.57 \pm 56.29,140.86 \pm$ 62.20 and $153.75 \pm 53.82$ days for the same systems, respectively. Furthermore least squares means $\pm S D$ of (NSPC) were $3.05 \pm 2.52,2.22 \pm 1.30,2.01 \pm 0.48,1.38 \pm 0.68,1.33$ \pm 0.57 and $1.65 \pm 0.78$ services (CS), (GS), (GR), (TLL), (TMS) and (TIS), respectively. All production systems showed imbalanced herd structure.
\end{abstract}

Key words: Dairy production systems, Buffalo, Cattle, Characterization, performance traits

\section{INTRODUCTION}

Agriculture is a key sector in the Egyptian economy, providing livelihoods for $55 \%$ of the population and provides about $30 \%$ of employing (FAO, 2012). Milk production plays an important role in the livelihoods of the people in Egypt and the need to expand milk production in Egypt is an urgent necessity due to the increase in population and the increase in the demand for dairy products year after year. Average annual milk production in Egypt is $\mathbf{5 . 2 8}$ million tons which increases annually by about $6.5 \%$ (Mohamed et al., 2008). 
Livestock sector globally is highly dynamic. In developing countries, it is evolving in response to rapidly increasing demand for livestock products. In general livestock production systems can be considered as a complex system of organizational structures and processes. So far there is no accurate description of production systems in Egypt.

Most research indicates that milk production systems in Egypt are only two basic systems (industrial - traditional mixed). Abdel Aziz and Sadek (1999) and Tabana (2000) reported that there are two major systems of dairy production; the first system is the mixed traditional crop/livestock system and the second system is the industrial system (intensive, commercial farms). Abol Khair Sala (2012) reported that the two major milk production systems in Egypt are the traditional crop/livestock which holds about $96 \%$ of the cattle and buffalo population and the "industrial" intensive production system which contains large commercial farms.

In a general overview it is clear that there is multiple dairy production systems needed to clarify thier productive and reproductive performance.

In Egypt, the problem statement is there is a shortage of information about traditional milk sector and its contribution to milk supply. Huge amount of milk is produced by smallholders through informal milk chain. Around $80 \%$ of the milk demand is provided by the traditional and informal sector (Census, 2010).

So, The present study was conducted to describe six different cattle and buffalo dairy production systems which represents the most distributed dairy systems in Egypt to understand the present dairy livestock production systems and to know in detail about these systems and its structure.

Information concerning dairy production systems may be useful to monitor the advantages and disadvantages of each system, consequently, it represents the more effective means by which animals adapt to various environmental factors and give us large view for the structure of dairy animal herds in Egypt.

\section{MATERIALS AND METHODS}

The data concerning productive and reproductive performance of six dairy production systems being maintained in Egypt were collected during the period between October 2014 and September 2015. Data collected included Commercial farms (CS), Government commercial (GC), Government research farm (GR), Traditional Landless system (TLL), Traditional mixed system (TMS) and Traditional intensive system (TIS). Land used production systems were randomly selected for interviewing the owners during "single visit monitoring". In order to compare various production systems, milk production has been modified to $4 \%$ fat corrected milk (FCM). As a comparative criteria productive and reproductive performance (i.e. number of services per conception (NSPC), service period (SP), calving interval $(\mathrm{Cl})$, lactation length (LL), average daily milk yield (DMY) and total milk yield (TMY) were also studied.

\section{Characterization of Dairy Production Systems Commercial system (CS)}

This system consists of 2000 heads of Holstein Friesian cattle including 850 dairy cows. Animals were housed free in shaded open yards, grouped according to their average daily milk yield and pregnancy status. Feeding was offered according to milk production and physiological status as recommended 
bye (NRC,1989). Feeding offered in three equal meals daily at 8.00 a.m., 2.00 p.m. and 8.00 p.m. using Total Mixed Ration (TMR) technique. Clean water was available ad lib in build basin water.

Cows were inseminated artificially after 60 days post partum using frozen imported semen (Friesian Bulls).

Dairy cows were machine milked three times daily at $04.00 \mathrm{~h}, 12.00 \mathrm{~h}$, and $17.00 \mathrm{~h}$ by milking parlor. No food was offered during milking.

\section{Government commercial system (GS)}

This system consists of 150 head of Holstein Friesian cattle including 100 dairy cows. Animals were housed free in shaded open yards, grouped according to their average daily milk yield and pregnancy status.

Animals were fed on Berseem (Trifolium alexandrinum) from November to May and on Berseem hay and silage (Corn silage) from June to October. All over the year cows were also fed concentrate supplementary ration (containing at least $14 \%$ - 16\% crude protein and $65 \%$ total digestible nutrient) and rice straw.

Feeding allowances were offered according to milk production and physiological status as recommended by NRC (1989). Clean water was available ad lib in built basin water and/or automatic drinkers. Feeding occurs according to the specific measure of dietary needs and which can be exchanged as follows: $1 \mathrm{~kg}$ of concentrates feed could be replaced with 6-8 $\mathrm{kg}$ Berseem (Trifolium alexandrinum), or $\mathbf{2} \mathrm{kg}$ Berseem hay, or 3 $\mathrm{kg}$ silage (Corn silage), or $3 \mathrm{~kg}$ of rice straw.

Concentrate feed mixture were offered in two equal meals daily at 7.30 a.m. and 11.00 p.m. Rice straw offered once time daily at 9.00 a.m., while fresh Berseem or
Berseem hay or corn silage were offered two times daily at 11 a.m. and 3.00 p.m.

In general, cows were inseminated artificially after 60 days post-partum using frozen imported semen (Friesian Bulls). In a few cases Holstein Friesian bulls were used for natural insemination with repeat estrus cows more than 3 times and no fertilization occurs. Dairy cows were milked twice daily at $\mathbf{0 4 . 0 0}$ a.m. and 18.00 p.m. except fresh cows and high yielding above $15 \mathrm{~kg}$ cows, they were milked three times daily at $\mathbf{0 4 . 0 0}$ a.m., 12.00 p.m., and 18.00 p.m. . Dairy cows were machine milked by milking parlor. No food was offered during milking.

\section{Government research system (GR)}

It is a Government farm belonging to the Faculty of Agriculture, Menoufia University and consists of 29 dairy Buffaloes maintained for teaching, extension, and research purposes. The GR farm is comprised of multiple barns to accommodate animals of different ages and to facilitate different types of research. Most buffalos are housed in tie stalls to control and measure feed intake during research. The farm was managed according to Governmental economic rules. Animals were fed on Berseem (Trifolium alexandrinum) from November to May and on Berseem hay and silage (Corn silage) from June to October. All over the year buffaloes were also fed concentrate supplementary ration containing at least $14 \%-16 \%$ crude protein and $65 \%$ total digestible nutrient and rice straw. Feeding allowances were offered according to milk production and physiological status. Clean water was available ad lib in automatic drinkers. Buffalo females were inseminated naturally after 60 days post-partum.

Dairy Buffaloes were machine milked twice daily at 05.00 a.m. and 04.00 p.m. by two unit Conveyor Milking machines. 
Traditional system (TS)

Smallholders dairy farming is increasingly becoming an important source of livelihoods for small scale dwellers in Egypt. Data of two hundred and ninety-four (294) farms presents broad sector of breeders in Egypt situated in Menoufia province were investigated. This broad sector of traditional breeders and milk producers in Egypt could be divided into the following production systems:

\section{Traditional Landless system (TLL)}

Landless livestock systems refer to those systems where livestock are raised on a minimum area of land, generally on land that is not dedicated to the purpose of keeping livestock. This production system is defined by the use of ruminant species, principally cattle, where feed is mainly introduced from outside the farm. The data included 37 one barn farms with an average of 1.9 dairy animals (ranged from 1-4 head) maintained for milk production. Animals were fed according to available feed randomly and inseminated naturally during the second heats after post-partum. In some cases cows were artificially inseminated. Clean water was available in drinker's basins or drinking bucket for all animals in specific times on the day round.

\section{Traditional mixed production system (TMS)}

TMS is a mixed crop-livestock farming system consists of integrated crop and livestock activities. Livestock feeding in this system depend on green fodder produced from the field and crop residues. This farming system had little access to pasture and support services. The land size did not exceed 2 acres and a barn. This type of farming system does not cover all family living expenditure. The present study included 210 farms consists of local cows and buffaloes (occasionally cross cows) with an average of 1.62 dairy animal (ranged between 1-3 head). A majority of the farmers do not provide animals with concentrates and depend on natural grass only. Animals were fed on Berseem (Trifolium alexandrinum) from the first of October to May and on silage (Corn silage) from June to October. Wheat and/or rice straw were offered all year around. However feeding allowances were offered according to available feed.

Dairy animals were inseminated naturally within $12-15$ hours after the detection of heat using selected bulls. In some cases cows were artificially inseminated (AI) in the case of the possibility of obtaining Al.

Cows were manually milked twice daily in the morning and evening time. Time of feeding has no exact pattern. Clean water was available in drinker's basins or drinking bucket for all animals in specific times on the day round.

\section{Traditional intensive production system (TIS)}

This farming system comprises farms with greater than 3 dairy animals. The data included 48 farmers. Farm consists of 3.89 dairy cattle in average ranged from 3 to 7 head maintained for milk production. They use high yielding local cows as well as some graded cows or cross-bred and buffaloes. The land size is 2.5 acres. Agricultural crops and their residues are used for feeding. Concentrated feed is relatively high in this system and a majority of the farmers provide concentrates beside straw food. Animals were fed on Berseem (Trifolium alexandrinum) from first of October to May and on silage (Corn silage) from June to October and were also fed wheat straw or rice straw all year around. Feeding allowances were offered according to available feed.

Nutrition courses are offered at relatively regular times. Clean water was 
available in drinker's basins or drinking bucket for all animals in specific times on the day round.

\section{Data analysis}

Data were statistically analyzed using Microsoft Excel 2007. Descriptive statistics such as means, standard deviation (SD) and percentages were generated by using the Statistical Package for Social Sciences (SPSS) software program version 20 (2015). The differences among the variables was analyzed using a one-way analysis of variance (ANOVA).

\section{RESULTS AND DISCUSSION}

\section{Breeds and species distribution}

As showing from Table (1) buffaloes represented the higher percentage of dairy animals in Traditional Systems (77-
$80 \%$ buffaloes and $20-23 \%$ cows). These results were in agreement with the finding of Soliman (2004) and Borghese (2005) who reported that dairy buffaloes in traditional small farm system shares by $60 \%$ of total milk production in Egypt. Pereira and jayasuriy (2008) reported that buffaloes are the main dairy animal to the majority of smallholder farmers in many developing countries. Also, FAO (2012) and Radwan et al. (2016) reported that there was aggregate share of buffalo milk, from all types of production systems, reaches about $81 \%$ of total milk production in Egypt.

As shown in Table (2) and Figure (1) there are significant differences among productive traits of dairy cattle in different production systems.

Table (1): Dairy breeds and species distributed in different dairy production systems

\begin{tabular}{|c|c|c|c|c|c|c|}
\hline Items & (CS) & (GS) & (GR) & (TLL) & (TMS) & (TIS) \\
\hline $\begin{array}{c}\text { Species \& } \\
\text { Breeds }\end{array}$ & $\begin{array}{c}\text { Holstein } \\
\text { Friesian cows }\end{array}$ & Buffaloes & \multicolumn{2}{|c|}{$\begin{array}{c}\text { Cross-bred (Balady X Friesian), } \\
\text { Local cows and Buffaloes }\end{array}$} \\
\hline $\begin{array}{c}\text { Total } \\
\text { Numbers }\end{array}$ & 1245 cows & $\begin{array}{c}101 \\
\text { Buffaloes }\end{array}$ & $\begin{array}{c}14 \text { cows } \\
+47 \text { buffaloes }\end{array}$ & $\begin{array}{c}63 \text { cows } \\
+231 \\
\text { buffaloes }\end{array}$ & $\begin{array}{c}32 \text { cows } \\
+130 \\
\text { buffaloes }\end{array}$ \\
\hline$\%$ Cows & $100 \%$ & 0 & $23 \%$ & $21 \%$ & $20 \%$ \\
\hline $\begin{array}{c}\% \\
\text { Buffaloes }\end{array}$ & 0 & $100 \%$ & $77 \%$ & $79 \%$ & $80 \%$ \\
\hline
\end{tabular}

Table (2): Least squares means \pm SD of different productive traits for different breeds and species

\begin{tabular}{|c|c|c|c|}
\hline \multirow{3}{*}{$\begin{array}{l}\text { Breeds } \\
\& \\
\text { Species }\end{array}$} & \multicolumn{3}{|c|}{ Productive traits } \\
\hline & TMY(kg/head) & DMY(kg/head) & LL(day/head) \\
\hline & ** & ** & ** \\
\hline Holstein Friesian in (CS and GS) & $7024.41^{a} \pm 4554.52$ & $20.78^{a} \pm 10.19$ & 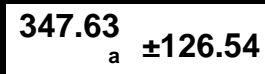 \\
\hline Buffaloes in (GR) & $1844.65^{c} \pm 461.75$ & $6.81^{\mathrm{c}} \pm 3.85$ & $271.04^{b} \pm 92.21$ \\
\hline $\begin{array}{l}\text { Buffaloes } \\
+ \text { Local cows +Cross bred cows } \\
\text { in (TLL,TMS and TIS) }\end{array}$ & $2761.47^{b} \pm 312.36$ & $10.97^{b} \pm 2.13$ & $254.83 \quad \pm 24.70$ \\
\hline
\end{tabular}

a, b,c: Different superscript means significant differences among breeds $(P<0.001)$

** = Highly significant $P<0.001$

TMY: Total Milk Yield ; DMY: Daily Milk Yield ; LL: Lactation Length 


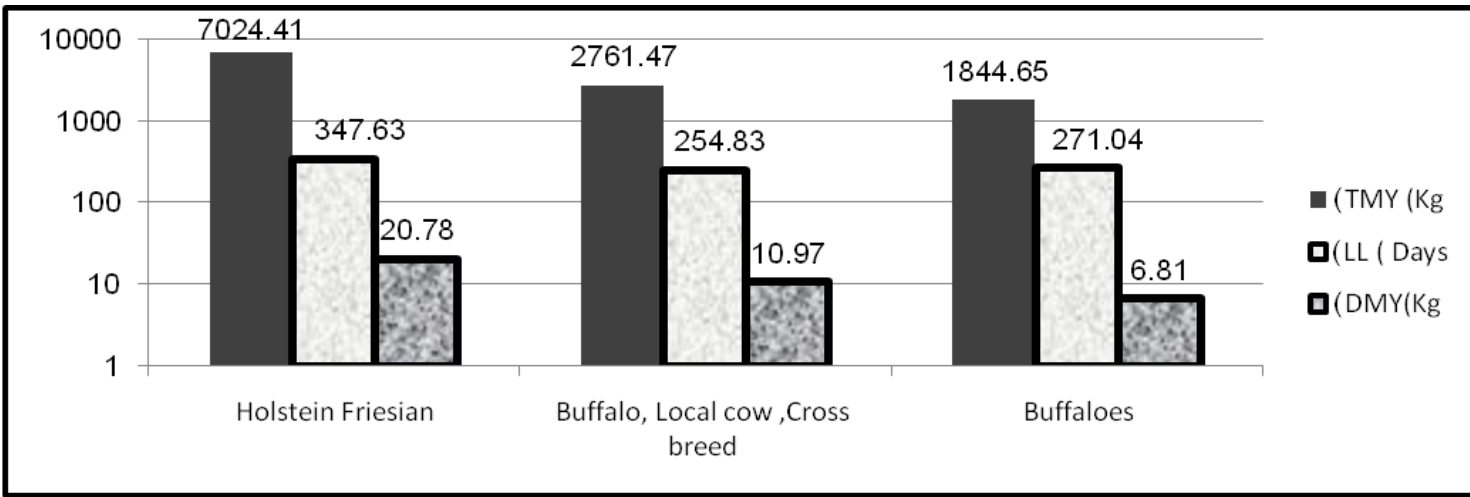

Figure (1): Illustration of Total Milk Yield (TMY), Lactation Length (LL) and Daily Milk Yield (DMY) for different breeds and species

Holstein Friesian cows recorded $7024.41 \pm 4554.52 \mathrm{~kg}$ for TMY with an average of $20.78 \pm 10.19 \mathrm{~kg}$ for DMY which was associated with lactation length of $347.63 \pm 126.54$ days in two production systems (CS and GS). While systems raised Buffaloes only, such as GR, reached $1844.65 \pm 461.75 \mathrm{~kg}$ for TMY with an average of $6.81 \pm 3.85 \mathrm{~kg}$ for DMY which was associated with lactation length of $271.04 \pm 92.21$ days. Dairy systems that raising Cross-bred, Local cows and Buffaloes such as in TLL, TMS and TIS all of them came in the middle where they recorded $2761.47 \pm 312.36 \mathrm{~kg}$ for TMY with an average daily milk yield of $10.97 \pm 2.13 \mathrm{~kg}$ which was associated with $254.83 \pm 24.70$ days lactation length.

Atallah et al. (2015) determined the effect of different dairy breeds on productive and reproductive traits. They indicated that the breed significantly affected $(P<0.01)$ all studied productive and reproductive traits. Maler (2010) reported that the milk production in Egypt is less than the threshold of selfsufficiency because of low milk production of local breeds; exotic breeds are adopted to increase milk production in commercial herds where intensive systems were followed. Busato et al. (2000) pointed out that differences in udder conformation and milking characteristics between dairy breeds could be the reason of milk yield differences.

\section{Herd productive traits}

Total milk yield and fat corrected milk

The lactation performance of dairy cattle is usually measured by determining the total milk yield per lactation, average daily milk yield and lactation length. Milk yield is the most important single determinant of profit for the dairy cattle. Moreover, effects of lactation number, age, and season and year of calving on milk yield and lactation length are well known (Msanga et al., 2000 and Epaphras et al., 2004).

As shown in Table (3) least squares means \pm SD of TMY were $10613.95 \pm$ $2692.45 \mathrm{~kg}, 2715.19 \pm 1697.09 \mathrm{~kg}, 1844.65$ $\pm 565.45 \mathrm{~kg}, 1929.59 \pm 637.79 \mathrm{~kg}, 1861.51 \pm$ $714.71 \mathrm{~kg}$ and $2603.65 \pm 733.48 \mathrm{~kg}$ for (CS), (GS), (GR), (TLL), (TMS) and (TIS), respectively.

Differences in milk fat percentage in different dairy breed led to different fat quantities. Therefore, milk yield was modified to become a $4 \%$ fat corrected milk (FCM). The results for FCM shown in Table (3) were 10136.32 $2571.29,2470.82$ \pm 1544.36, 2813.09 \pm 862.32, 2858.44 \pm 1196.06, $2712.45 \pm 1270.82$ and 2901.17 \pm $853.08 \mathrm{~kg} / \mathrm{head}$ for (CS), (GS), (GR), (TLL), (TMS) and (TIS), respectively. 
Table (3): Means \pm SD for Total milk yield and fat corrected milk in different dairy production systems

\begin{tabular}{|c|c|c|cc|cc|}
\hline \multirow{2}{*}{$\begin{array}{c}\text { Dairy } \\
\text { production } \\
\text { systems }\end{array}$} & \multirow{2}{*}{$\begin{array}{c}\text { Number of } \\
\text { dairy heads }\end{array}$} & $\begin{array}{l}\text { Milk } \\
\text { fat\% }\end{array}$ & \multicolumn{2}{|c|}{ Actual Milk yield ( kg ) } & \multicolumn{3}{|c|}{$\begin{array}{r}\text { Fat corrected Milk yield } \\
(\mathrm{kg})\end{array}$} \\
\cline { 4 - 8 } & & & Mean & \pm SD & Mean & \pm SD \\
\hline CS & 837 & 3.7 & 10613.95 & \pm 2692.45 & $10136.32^{\mathrm{a}}$ & \pm 2571.29 \\
\hline GS & 408 & 3.4 & 2715.19 & \pm 1697.09 & $2470.82^{\mathrm{e}}$ & \pm 1544.36 \\
\hline GR & 101 & 7.5 & 1844.65 & \pm 565.45 & $2813.09^{\mathrm{c}}$ & \pm 862.32 \\
\hline TLL & 61 & 6.7 & 1929.59 & \pm 637.79 & $2858.44^{\mathrm{c}}$ & \pm 1196.06 \\
\hline TMS & 294 & 6.7 & 1861.51 & \pm 714.71 & $2712.45^{\mathrm{d}}$ & \pm 1270.82 \\
\hline TIS & 162 & 6.8 & 2603.65 & \pm 733.48 & $2901.17^{\mathrm{b}}$ & \pm 853.08 \\
\hline
\end{tabular}

a , b,c d Different superscript means significant differences among systems $(P<0.001)$

The results showed that there are highly significant differences in FCM $(P<0.001)$ among different dairy production systems according to milk fat quantity differences.

Total milk yield of Holstein Friesian cows were reported by some researchers and ranged from $3210 \pm 46 \mathrm{~kg}$ to 3977.75 $\pm 37.20 \mathrm{~kg}$ (Shalaby, 2001; Javed et al., 2011; Sattar et al., 2005; Amaniz et al., 2007 and Zahid et al., 2011). El-Awady (2012) indicated that the total milk yield was $5138 \pm 742 \mathrm{~kg}, 8719 \pm 839 \mathrm{~kg}$ and $13935 \pm 808 \mathbf{~ k g}$ for three Holstein Friesian herds in Egypt under intensive production systems.

On the other hand, results of TMY for dairy production systems raised buffalo breeds such as (GR), (TLL), and (TMS) were in agreement with estimates of $\mathrm{El}$ Kirabi, (1995); Borghese, (2005); Mostafa, (2012) in Egypt who reported that buffalo productivity is $1200-2100 \mathrm{~kg}$. While the global buffalo production was ranged by 1350 to 4500 liters in commercial per urban systems (Paisha, 2007and FAO, 2016).

\section{Daily Milk Yield}

Least squares means \pm SD of Daily
Milk Yield (ADY) were $27.78 \pm 5.53,9.41 \pm$ $3.74,6.81 \pm 2.02,7.37 \pm 2.68,6.22 \pm 2.49$ and $11.30 \pm 2.56 \mathrm{~kg} / \mathrm{head}$ for (CS), (GS), (GR), (TLL), (TMS) and (TIS) dairy systems, respectively. While, the average of $4 \%$ daily fat corrected milk were 26.14 $\pm 5.31,8.55 \pm 3.24,10.37 \pm 3.02,10.31 \pm$ $4.14,10.79 \pm 3.95$ and $12.24 \pm 4.25 \mathrm{~kg} /$ head, respectively (Table 4).

The results in Table (4) showed significant differences for daily milk yield among different dairy systems. Differences of DMY in both (CS) and (GS) systems was highly significant $(P<0.001)$ where it was $27.78 \mathrm{~kg} / \mathrm{cow}$ vs 9.41 $\mathrm{kg} / \mathrm{cow}$, respectively. Average of daily milk yield in (GS) was much lower than that expected for HF cows compared to the (CS) system, this may be due to poor management, lack of nutrition, lack of resources, low inputs and diseases which leads in general to low average milk production in (GS) where (CS) systems used breeding programs for genetic improvement and good management etc. These results came compatible with those of Khan et al. (2008) and Javed et al. (2011). In Egypt, some researchers reported higher estimated DMY such as El-Awady (2012); 
as $15.06 \pm 0.27,22.41 \pm 0.78$ and $26.32 \pm$ $0.64 \mathrm{~kg} / \mathrm{head} / \mathrm{day}$ for three herds of HF cows, respectively. While, Kassab and Salem (2000) reported that the average DMY was $13.2 \mathrm{~kg}$. Zaabal and Ahmed (2001) indicated that average daily milk production was $7.323 \pm 0.240$ ( $\mathrm{kg} /$ /day) for HF cows.

Differences in average daily milk yield among (GR), (TLL) and (TMS) were not significant where it was $10.37 \pm 3.02$, $10.31 \pm 4.14$ and $10.79 \pm 3.95 \mathrm{~kg}$, respectively.

Buffaloes Daily milk yield estimated as more than of local cows by many researchers (Ahmed and Hassan, 2007; FAO, 2012 and Mostafa, 2012) they concluded that average daily milk yield of local cows was 5-8 and 3-5 kg/head for winter and summer seasons, respectively. The corresponding results of buffaloes are 10-12 and 7-9 kg/head, respectively in Egypt.

\section{Lactation length}

Lactation length (LL) was estimated to be as the period between two consecutive calving during which cows are capable of producing milk and I or lactating.
As shown in Table (5) Least squares means \pm SD of $(L L)$ were $387.77 \pm 98.39$, $289.50 \pm 140.76,271.04 \pm 92.21,222.59 \pm$ $36.22,266.15 \pm 30.96$ and $230.12 \pm 28.96$ days for (CS), (GS), (GR), (TLL), (TMS) and (TIS) dairy production systems respectively. Average of LL for (CS) was higher than (GS) systems. This difference between the two systems was highly significant $(P<0.001)$ although both systems raised HF cows. This difference may be due to increase in the average of daily milk yield in (CS) system explained by differences in number of parities, age of cow, plane of nutrition, environmental and management system (Sattar et al., 2005). Poor feeding management of potentially high yielding cows can create many problems. Lactation in estrus can occur as the cows are forced to utilize more of their body reserves in early lactation. This can lead to low peak milk yields and shortened LL. As mentioned in the present results, Commercial system is the only system using the technique of Total Mixed Ration (TMR), which can consequently affect the nutritional efficiency of animals.

Table (4): Means \pm SD of daily milk yield and fat corrected milk in different dairy production systems

\begin{tabular}{|l|c|c|c|}
\hline \multicolumn{1}{|c|}{ Dairy production systems } & $\begin{array}{c}\text { Dairy } \\
\text { animals } \\
\text { No. }\end{array}$ & $\begin{array}{c}\text { Actual daily milk } \\
\text { yield (kg) }\end{array}$ & $\begin{array}{c}\text { Fat corrected daily } \\
\text { milk yield (kg) }\end{array}$ \\
\hline Commercial system (CS) & 837 & $27.78 \pm 5.53$ & $26.14^{\mathrm{a}} \pm 5.13$ \\
\hline Government commercial system (GS) & 408 & $9.41 \pm 3.74$ & $8^{\mathrm{d}} \pm .55^{\mathrm{d}} \pm 3.24$ \\
\hline Government research system (GR) & 101 & $6.81 \pm 2.02$ & $10.37^{\mathrm{c}} \pm 3.02$ \\
\hline Traditional Landless system (TLL) & 61 & $7.37 \pm 2.68$ & $10.31^{\mathrm{c}} \pm 4.14$ \\
\hline Traditional mixed system (TMS) & 294 & $6.22 \pm 2.49$ & $10.79^{\mathrm{c}} \pm 3.95$ \\
\hline Traditional intensive system (TIS) & 162 & $11.30 \pm 2.56$ & $12.24^{\mathrm{d}} \pm 4.25$ \\
\hline
\end{tabular}

a, b,c d: Different superscript means significant differences among systems $(P<0.001)$ 
Table (5): Means \pm SD for Lactation length in different dairy production systems

\begin{tabular}{|l|c|cc|}
\hline \multicolumn{1}{|c|}{ Dairy production systems } & $\begin{array}{c}\text { Dairy animals } \\
\text { No. }\end{array}$ & \multicolumn{2}{|c|}{ Lactation length (days) } \\
\cline { 2 - 5 } & 837 & $387.77^{\mathrm{a}}$ & \pm 98.39 \\
\hline Commercial system (CS) & 408 & $289.50^{\mathrm{b}}$ & \pm 140.76 \\
\hline Government commercial system (GS) & 101 & $271.04^{\mathrm{c}}$ & \pm 92.21 \\
\hline Government research system (GR) & 61 & $222.59^{\mathrm{d}}$ & \pm 36.22 \\
\hline Traditional Landless system (TLL) & 294 & $266.15^{\mathrm{c}}$ & \pm 30.96 \\
\hline Traditional mixed system (TMS) & 162 & $230.12^{\mathrm{d}}$ & \pm 28.96 \\
\hline Traditional intensive system (TIS) & &
\end{tabular}

a , b, c: Different superscript means significant differences among systems $(P<0.001)$

Lactation length in (CS) system was higher than that of many researchers (Atil, 2000; Amaniz et al., 2007 and Atakan, 2011); they reported that LL was 300 days, $294.10 \pm 3.62$ days and $331.4 \pm$ 6.92 days, respectively for HF cows. Irshad et al. (2011) documented average of $L L$ of $320.14 \pm 11.14$ days with range of 299.6. \pm 13.64 to $356.93 \pm 12.50$ days. On the other hand, results of LL for (CS) were in agreement with finding of Usman et al. (2012) who reported that LL ranged from 185 to 514 days with mean of $366.5 \pm 76.71$ days. While it was less than the average reported by Oliveria (1975) who found $392 \pm 55.51$ days for other herd of Holstein Friesian cow's . Zahid et al. (2011) and Yousaf et al. (2011) reported that the maximum lactation length were $314.19 \pm 0.91$ days and $311.19 \pm 7.31$ days, respectively.

Furthermore, the results for LL of (GR) system which raised buffaloes, and Traditional systems came in agreement with Mostafa (2012) who reported that buffalo lactation length was about 210280 days. However Tonhati et al. (2004) reported that buffalo's lactation length is around 250 days but shorter lactations are common.
The optimum LL in Murrah Buffalo has been reported by Jailton da Silva et al. (2014) as 262 to 295 days with average of $282.59 \pm 39.48$ days. All Paedia (2016) reported that LL in Egyptian buffaloes was $\mathbf{1 8 0 - 2 9 1}$ days.

\section{Herd reproductive traits Calving interval}

Table (6) showed the least squares means \pm SD of calving interval for (CS), (GS), (GR), (TLL), (TMS) and (TIS) systems, respectively being, $438.30 \pm$ $112.77,470.75 \pm 113.43, \quad 533.67 \pm 91.89$, $387.57 \pm 56.29, \quad 410.86 \pm 62.20$ and $423.75 \pm 53.88$ days, respectively.

These results showed that calving interval of all systems were longer than the optimum one which ranged from 387 to 533 day. There are many reports indicated that calving interval of 12 to 13.5 months is considered as standard values of Holstein Friesian cows (McDowell, 1985 ).

There are significant differences in $\mathrm{Cl}$ among different production systems. The highest values for $\mathrm{Cl}$ was in the GR being 533.67 days, followed by GS and CS. The Traditional system, especially the TMS, had the lowest value of $\mathrm{Cl}$ being 387.57 days. 
Table (6): Least squares means \pm SD of calving interval; Service periods and Numbers of services per conception in different dairy production systems

\begin{tabular}{|c|c|c|c|c|}
\hline $\begin{array}{c}\text { Dairy } \\
\text { production }\end{array}$ & No. & $\begin{array}{l}\text { Calving Interval } \\
\text { (days) }\end{array}$ & $\begin{array}{l}\text { Service Periods } \\
\text { (days) }\end{array}$ & $\begin{array}{l}\text { Numbers of Services } \\
\text { per Conception }\end{array}$ \\
\hline systems & & Mean \pm SD & Mean \pm SD & Mean \pm SD \\
\hline (CS) & 837 & 438.30 b $\quad \pm 112.77$ & $163.12^{a} \pm 110.23$ & $3.05^{a} \pm 2.52$ \\
\hline (GS) & 408 & 470.75 cb \pm 113.43 & $107.72^{b} \pm 69.63$ & $2.22^{b} \pm 1.30$ \\
\hline (GR) & 101 & 533.67 a \pm 91.89 & $155.50^{\mathrm{a}} \pm 89.57$ & $2.01^{b} \pm 0.48$ \\
\hline (TLL) & 61 & $387.57^{c} \pm 56.29$ & $117.57^{b} \pm 56.29$ & $1.38^{c} \pm 0.68$ \\
\hline (TMS) & 294 & $410.86{ }^{c b} \pm 62.20$ & $140.86^{\mathrm{ab}} \pm 62.20$ & $1.33^{c} \pm 0.57$ \\
\hline (TIS) & 162 & $423.755^{b} \quad \pm 53.88$ & $153.75^{a} \pm 53.82$ & $1.65^{c} \pm 0.78$ \\
\hline
\end{tabular}

Average calving interval for (CS) and (GS) systems where HF cows were raised was longer than the optimum one. This may be due to the differences in the number of parities, age of cow, plane of nutrition, environmental and management system (Sattar et al., 2005).

In Egypt, Marizok (1998) reported that calving interval for locally-born Friesian cows and was 426 days. El-Sadafy (1989) and Zaabal and Ahmed (2001) reported that the calving interval was 423 and $398.050 \pm 2.429$ days for Holstein Friesian cows respectively.

Higher estimated calving interval of Holstein Friesian cows was reported by Sattar et al. (2005) and El Awady (2012) accounting for $505.02 \pm 8.28$ days and $635.0 \pm 8.6$, respectively.

On the other hand, results of calving interval for production systems which raised buffaloes such as Government research system (GR) was longer than the optimum one, but Traditional systems came in line with the finding of Barkawi et al. (1998) in Egyptian buffaloes who reported that buffalo's calving interval was ranged from 400.3 to 441.5 days. Ahmad et al. (2001) reported that buffalo calving interval ranged from 506.6 to 570.6 days.

\section{Service period}

Services period is the time taken from calving to next successful insemination (Khan, 2008). Table (6) showed the least squares means \pm SD of service period (SP) for (CS), (GS), (GR), (TLL), (TMS) and (TIS) systems, respectively systems which were $163.12 \pm 110.23,107.72 \pm$ $69.63,155.50 \pm 89.57, \quad 117.57 \pm 56.29$, $140.86 \pm 62.20, \quad 153.75 \pm 53.82$ days, respectively.

Service periods for six systems under study ranged from 107 to 163 days; it's longer than the optimum one, which the standard length of service periods is $\mathbf{6 0}$ days (USDA, 2014).

There are significant differences $(P<0.001)$ in SP among different production systems. However there were no significant differences in SP among CS, GR, TIS and TMS systems, being $163.12,155.50,153.75$ and 140.86 days, respectively. GS and TLL had the lowest values of SP being, 107.72 and 117.57 days, respectively. Higher estimate of (SP) reported with (CS) being $163.12 \pm 110.32$ days, while (GS) had the 
lowest service period being, $107.72 \pm$ 69.63 days although both systems raised Holstein Friesian cows. These differences may be due to that the commercial system has the largest productivity systems of total milk yield and daily milk yield which are inversely associated with fertility. Tadesse et al. (2010) and Zahid et al. (2011) documented that the average of service period was $129.95 \pm 2.14$ days with a range of $121.23 \pm 2.14$ days to $136.92 \pm 2.33$ days in Holstein Friesian cows. However Kassab and Salem (2000) reported a higher average value for service period (171.2 days).

Results of service period for production systems raised buffaloes such as (GR) and Traditional systems were less than many global estimated values such that reported by Javed et al. (2011) who found that SP was $249 \pm 15.36$ days and Quereshi et al. (1999) who reported that least squares mean for SP was $\mathbf{1 6 2 . 0}$ days and ranged between $\mathbf{6 7 . 2}$ -220.5 days. On other hand lower estimates of SP ranged from $\mathbf{7 0 . 3}$ to $\mathbf{9 8 . 0}$ days was reported by Arya and Madan (2001).

\section{Number of services per conception}

Table (6) showed the least squares means $\pm S D$ of numbers of services per conception (NSPC) for (CS), (GS), (GR), (TLL), (TMS) and (TIS) being, $3.05 \pm 2.52$, $2.22 \pm 1.30,2.01 \pm 0.48,1.38 \pm 0.68, \quad 1.33$ $\pm 0.57,1.65 \pm 0.78$ services respectively.

As shown in Table 6 the NSPC were higher in some systems than the optimum one and varied between 1.3 and 3.0. However many reports indicated that the NSPC of 1.3 to 1.5 services are considered as standard values (McDowell, 1985). Zahid et al. (2011) reported that the NSPC was 2.8 services. In Egypt, El Awady, (2012) reported that
(NSPC) were ranged from $1.53 \pm 0.04$ to $3.44 \pm 0.09$ services.

On the other hand Zaabal and Ahmed (2008) estimated lower value of (NSPC) as $(1.30 \pm 0.146)$ in HF cows in Egypt. Javed et al. (2011) reported that the least squares mean of (NSPC) was $1.99 \pm 0.13$ services, however, the maximum and minimum least squares mean of the (NSPC) were $2.29 \pm 0.33$ and $1.21 \pm 0.24$ services, respectively.

Goshu et al. (2007) and Tadesse et al. (2010) reported that the overall mean for (NSPC) was $1.720 \pm 0.056$ and $1.80 \pm 1.00$ services, respectively in Holstein Friesian cows.

Furthermore results of (NSPC) for production systems which raised buffaloes such as GR system and Traditional systems were less than many global estimates. Kotby et al. (1987) reported that least squares mean for (NSPC) was 1.87士 0.07 services from 344 buffaloes at 2 farms. javed et al. (2011); Ahmed et al. (2001) and Quereshi et al.(1999) reported that least squares means for (NSPC) were $1.99 \pm 0.13,2.15 \pm$ 0.04 and 2.0 services, respectively.

On the other hand, lower estimate of (NSPC) in buffaloes reported by Shafique and Usman (1996) it was $1.30 \pm 0.01$ services.

Furthermore there are significant differences in the (NSPC) between the CS and GS systems ( $P>0.005)$, while the differences are not significant between the GS and GR systems. The differences among the three Traditional systems were also non-significant.

The number of services per conception depends largely on the breeding system used and were significantly affected by lactation length and milk yield (Quereshi et al., 1999). However Mukasa-Mugered (1989) reported that (NSPC) depends largely on the breeding system used and are higher 
under uncontrolled natural breeding and lower where hand-mating or artificial insemination is used.

\section{Herd structure}

Table (7) showed that commercial systems have $41.3 \%$ of cows exist in the first parity, followed by second parity $(22.6 \%)$, third parity (15.8\%) and fourth parity (14.1\%) respectively, then a significant decline in number occurred in the fifth parity (3.2\%) that explains the administration's policy of push the largest number of heifers in the first parity and then pick the best ones for the third parity of the largest productive seasons.

The same distribution exists in GS system, which have more than $47.7 \%$ of cows in the first parity, followed by second parity (20.0\%), third parity (11.2\%) and fourth parity (8.1\%), while a significant decline in number occurred in the fifth parity (5.6\%). Also GR system have more than $(28.4 \%)$ of the cows exist in first parity, followed by second parity (23.5\%) and third parity (16.7\%) and fourth parity (12.7\%), while a significant decline in number occurred the fifth parity $(4.9 \%)$ with $13.7 \%$ of animals celebrating the fifth season. Traditional production systems have also shown varying proportions of dairy herd components ranged between $10-30.0 \%$ and $\mathbf{5 . 9 - 2 9 . 4 \%}$ for cows and buffaloes respectively raised in TLL, TMS and TIS.

Dairy herd structure influences the overall herd performance and the ability to maintain constant output from the herd. Herd performance varies considerably according to parity, if herd parity changes over a period of time, production variation will be increased and immunity will be affected. The ideal situation is where there is a steady flow of replacement heifer into the herd and a good spread of females across the parity range (Patrick et al., 2015).

A number of cows in a dairy herd will be culled each year for reasons of low milk yield, infertility, disease, old age, etc. These cows are best replaced with young stock from their own herd, since any animals acquired from outside the farm may bring disease to the herd (EI Kaschab, 1998).

In general, all production systems showed a non-typical herd structure and this does not allow for a good herd replacement.

Table (7) Dairy herd structure in different production systems

\begin{tabular}{|c|c|c|c|c|c|c|c|c|c|}
\hline \multirow{3}{*}{$\begin{array}{c}\text { Lactation } \\
\text { No. } \\
\text { (parity) }\end{array}$} & \multicolumn{9}{|c|}{ Production systems } \\
\hline & (CS) & (GS) & (GR) & \multicolumn{2}{|c|}{ (TLL) } & \multicolumn{2}{|c|}{ (TMS) } & \multicolumn{2}{|c|}{ (TIS) } \\
\hline & HF cows & HF cows & Buffaloes & cows & Buffaloes & cows & Buffaloes & cows & Buffaloes \\
\hline 1 & $41.3 \%$ & $47.7 \%$ & $28.4 \%$ & $20.0 \%$ & $8.8 \%$ & $28.6 \%$ & $20.5 \%$ & $29.2 \%$ & $15.2 \%$ \\
\hline 2 & $22.6 \%$ & $20.0 \%$ & $23.5 \%$ & $30.0 \%$ & $29.4 \%$ & $24.5 \%$ & $18.5 \%$ & $20.8 \%$ & $19.6 \%$ \\
\hline 3 & $15.8 \%$ & $11.2 \%$ & $16.7 \%$ & $30.0 \%$ & $35.3 \%$ & $22.4 \%$ & $20.0 \%$ & $20.8 \%$ & 28.3\% \\
\hline 4 & $14.1 \%$ & $8.1 \%$ & $12.7 \%$ & $10.0 \%$ & $8.8 \%$ & $14.3 \%$ & $9.2 \%$ & $16.7 \%$ & $26.1 \%$ \\
\hline 5 & $3.2 \%$ & $5.6 \%$ & $4.9 \%$ & $10.0 \%$ & $11.8 \%$ & $10.2 \%$ & $15.4 \%$ & $12.5 \%$ & $10.9 \%$ \\
\hline $5 \geq$ & $3.0 \%$ & 7.3\% & $13.7 \%$ & $0.0 \%$ & $5.9 \%$ & $0.0 \%$ & $16.4 \%$ & $0.0 \%$ & $0.0 \%$ \\
\hline $\begin{array}{l}\text { Total No., } \\
\text { of dairy } \\
\text { animals }\end{array}$ & 837 & 408 & 101 & 14 & 47 & 63 & 231 & 32 & 130 \\
\hline
\end{tabular}




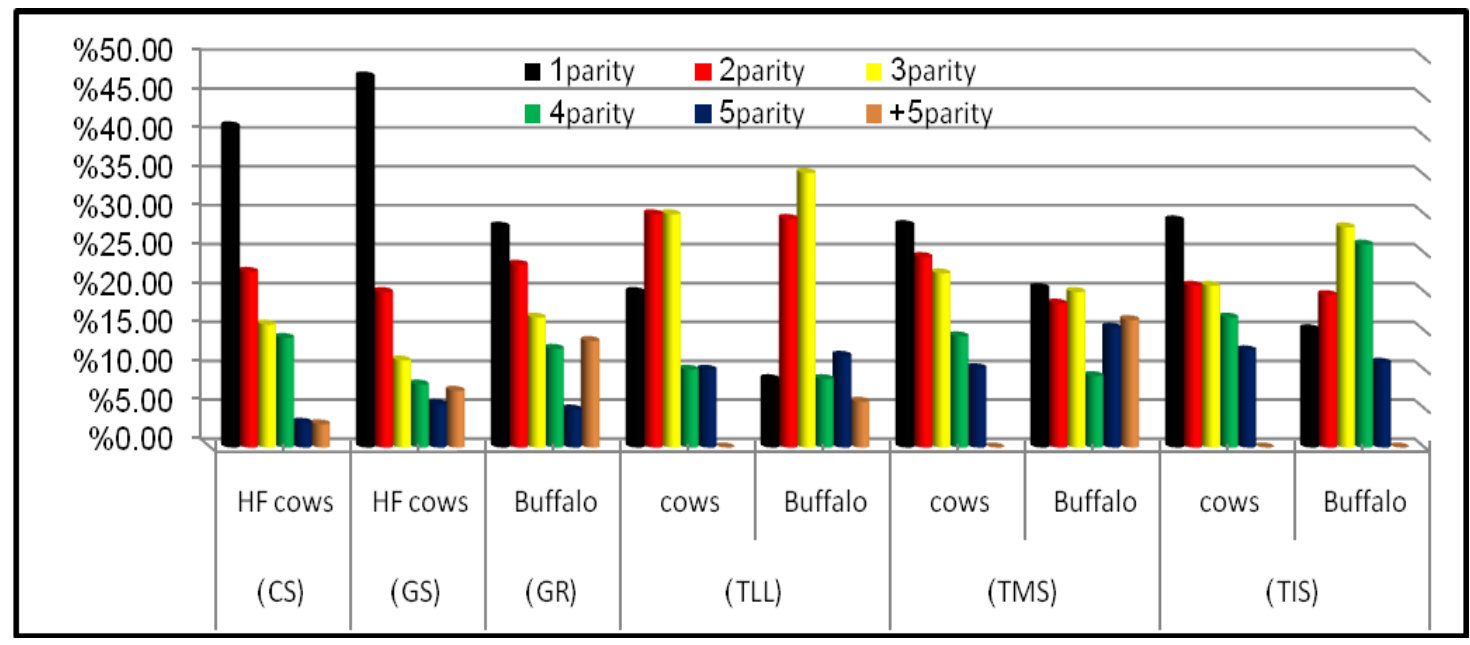

Figure (2): Illustration of dairy herd structure within different production systems

Commercial system showed that structure difference between the first lactation and the fifth lactation is about 38\% (Table 7). Also GS system showed that the differences about $40 \%$. On the other hand GR system and Traditional system showed structure difference of about 25\%. Stewart (2015) reported that the difference in age structures must be considered when making comparisons among herds. For this reason, it is usual in some countries, notably the USA, to convert all milk yields to mature equivalents before calculating herd averages.The difference between a first lactation and a mature lactation is about $25 \%$ in most herds, so the conversion will make a significant difference. El Kaschab (1998) reported that cows are commonly culled after three to five lactations, corresponding to a replacement rate of 20 to $30 \%$ per year. However, John Hibma (2010) reported that the average annual culling per replacement rate for the same dairy herds is around $30 \%$ almost onethird of the milking herd. Whether a dairy is milking 100 cows or 1,000 cows, herd replacement expenses represent a significant cost of doing business. The annual culling rate in the Netherlands and UK was range from 21 to $30 \%$ while in the United States, the annual culling rate among herds ranged from 34 to $36 \%$ (Sol et al., 1984 and Smith et al., 2000). The average replacement rate on UK dairy farms is $30 \%$ but there is variation between farms among $11 \%$ and $62 \%$ in a recent survey (Julia, 2017).

The percentage of dairy cows within the third parity is very low compared with the percentage of dairy cows in the first parity in Commercial System $\mathbf{( 4 1 . 3 \%}$ vs.15.8\%), Government Commercial System $(47.7 \%$ vs. $11.2 \%)$ and GR system (28.4\% vs.16.7\%) (Table 7). Traditional systems showed a larger percentage of dairy animals in the third parity compared to the first one $\mathbf{3 0 . 0 \%}$ cows and $35.3 \%$ buffaloes vs. $20.0 \%$ cows and $8.8 \%$ buffaloes for TLL; $28.6 \%$ cows and $20.5 \%$ buffaloes vs. $22.4 \%$ cows and $20.0 \%$ bufalloes for TMS and $20.8 \%$ cows and $28.3 \%$ buffaloes vs. $29.2 \%$ cows and 15.2\% buffaloes for TIS (Table 7).

However many researches confirm that the third parity has the highest milk production. Lateef et al. (2008) reported that milk yield of HF cows was higher in second and third than fourth and fifth parities and the effect of parity on milk yield was highly significant $(P<0.001)$. 
General Discussion and conclusion

The objective of this study was to characterize the most distributed diary production systems in Egypt according to production elements.

The results about production characterization in different production systems revealed that some breeders prefer to combine buffaloes and cows in one production system such as in Traditional systems. The aim of these breeders was to produce the appropriate milk for community needs surrounding the farm.

There are significant differences among productive traits in different dairy production systems. These differences confirm that the production systems are different in animal breeds, feeding systems, breeding systems and management systems, in addition to the different purpose and the main objective of the production which could be affect milk produced cost within each system.

It is noted in the present study that the average of reproductive traits were higher than the optimum one, which led to losses in the production system and increase production costs. On-farm reproductive management could be identifying the problem cows, which can be effectively treated. Missing one estrus extends the calving interval in cows and the age at first calving in heifers by about 21 days which could be in turn resulting in economic losses. Length of calving interval or service period leads to reduced annual milk production, high feeding costs, problems in the replacement and higher levels of involuntary replacement of the herd, and the farm is forced to sell animals at a low price. The main findings of the present study are that farmers miss estrus in a high percentage of cows. On-farm reproductive management could be identifying the problem cows, which can be effectively treated.
All production systems studied did not have balanced herd structure which could be affecting the replacement rate in the herd and all milk production levels. This will affect the cost of milk production within each system.

Finally, it can be concluded that all Traditional milk production systems and Government production systems needs only an appropriate decision maker who can improve production using the available production elements.

\section{REFERENCES}

Abdel Aziz, A. and R.R. Sadek (1999). Policy Issues in the Dairy Sub Sector. 46 P., workshop on production, processing and marketing policy issues in the dairy sub-sector, November 1999, Giza, Egypt.

Abol Khair, Sala A. I. (2012). Study on the use of some bioactive compounds from whey to develop the manufacture milk products in Egypt Submitted in partial fulfillment of the requirements. For the degree of DOCTOR OF PHILOSOPHY. In African Studies and Natural Resources). Institute of African Research and Studies, Cairo University

Ahmad, N., R. Hussain and K. Javed (2001). Effect of some environmental. The J Ani PI Sci 2001; 11(4): 147-49.

Ahmed, W.M. and S.E. Hassan (2007). Applied studies on coccidiosis ingrowing buffalo-calves with special reference to oxidant/antioxidant status. World J. Zool., 2:40-48.

All Paedia (2016). Egyptian buffalo breed allpaedia.com/mobile/livestock/breeds /buffalo.../3387-egyptian buffalobreed.html and stabilizing agricultural production

Amaniz Abdel Gader, K. Mohamed and A. Musa (2007). Milk yield and reproductive performance of Friesian cows under Sudan tropical conditions Article in Archiv fur Tierzucht . 
October 2007 DOI: 10.5194/aab-50-1552007.

Arya, J.S. and M.L. Madan (2001). Post partum reproductive cyclicity based on ovarian steroids in suckled and weaned buffaloes. Buffalo J., 17 (3): 361-369.

Atallah, S.T., I. Ahmed and Eman M. ElKtany (2015). Some Factors affecting Profitability of Dairy Farms Alexandria J Vet Sci. 2015; 45(1): 119-126doi: 10.5455/ajvs.181-183

Atil, H. (2000). Genetic relationship between days open and days dry with milk yield in a herd of Holstein Friesian cattle. Arch. Tierz., Dummerstorf 43 (2000), 583 - 590

Barkawi, A.H., R.M. Khattab and M.A. ElWardani (1998). Reproductive efficiency of Egyptian buffaloes in relation to oestrus detection systems. Anim. Reprod. Sci., 51: 225-231.

Borghese, A. (2005). Buffalo Production and Research. FAO Regional Office for Europe. Proc. of the Inter-Regional Cooperative Research Network on Buffalo (ESCORENA), Rome.

Busato, A., P. Trachsel and J.W. Blum (2000). Udder health and risk factors for subclinical mastitis in organic dairy farms in Switzerland. Prev. Vet. Med., 44: 205-220.

Census (2010). Census of Agriculture 2010/11 Steering Committee for the Agricultural Census Agricultural Census Office.

El Kaschab, S. (1998). Milk production. Book Published by El Dar El Arabia, Cairo EGYPT-ISBN:977-258-130-2 .

El Kirabi, E. (1995). Buffalo population and production in Egypt. Buffalo Newsletter, 3: 8.

El-Awady (2012). Effect of Milk Yield on Economic Profitability of Holstein Friesian Cows under Intensive Production System in Egypt Pakistan Veterinary Journal ISSN: 0253-8318 (PRINT), Faculty of Agriculture,
Kafrelsheikh University, PC: 33516 , Kafrelsheikh, Egypt

El-sadafy, E.R. (1989). Some Reproductive parameters in Friesian cattle in Egypt, M.Sc.thesis, AinShams Univ., Cairo, Egypt.

Epaphras, A., E.D. Karimuribo and S.N. Msellem (2004). Effect of season and parity on lactation of crossbred Ayrshire cows reared under coastal tropical climate in Tanzania. Livestock Research for Rural Development. 2004; (16)6.

FAO, (2012). Livestock, environment and development (LEAD) initiative. Livestock and Environment Toolbox. http://www.fao.org/lead/toolbox/home page.htm.

FAO, (2016). Animal production and health paper Current Status, Issues and Trends NO.127, World Livestock Production Systems

Goshu, G., K. Belihu and A. Berihun (2007). Effect of Parity, season and year on reproductive performance and herd life of Friesian cows at Stella private dairy farm, Ethiopia. Lives. Reas. Rur. Dev. 19 (7)

Irshad, A., M.M. Tariq, A. Waheed and K.U. Khan (2011). A study on performance analysis of HolsteinFriesian cattle herd under semi intensive management at Pishin Dairy Farm Balochistan. Journal of Institute Science and Technology, 1: 53-57.

Javed, N. Ahmad and S. U. Rehman (2011). Environmental Factor affecting some reproductive traits in Nile Ravi Buffaloes. The Journal of Animal \& Plant Sciences, 21(4): 2011, Page: 868871 ISSN: 1018-7081

Julia, A.B. (2017). Moor house of EBVC takes a look, as part of the Decisions 4 Dairy cost of production theme https://dairy.ahdb.org.uk/news

Kassab, M.S. and A.Y. Salem (2000). Estimation of genetic parameters and selection indices for some dairy traits in the first lactation of Friesian cows. J. Agric. Res. Tanta Univ. Egypt, 25: 39-39 
Khan, M.S., Z.M. Rehman, A. Khan and S. Ahmad (2008). Genetic resources and diversity in Pakistani cattle. Pakistan Veterinary Journal, 28: 95- 102.

Khan, M. A. (1986). Genetic analysis of a purebred herd of Nili Ravi buffaloes. PhD Thesis, Deptt. Anim. Breed. Genetics, Univ. Agri. Faisalabad, Pakistan.

Kotby, EA., L. H. Bedeir, H. E. E. I. Sobhy and L. N. Eid (1987). The reproductive performance of Egyptian buffaloes as influenced by some environmental factors., Ain Shams University, Cairo, 19-21 Dec, 1987. J. Anim. Production., 1(36): 1-11.

Lateef, M., K. Z. Gondal, M. Younas and M. K. Bashiri (2008). Milk production potential of pure bred Holstein Friesian and Jersey cow in subtropical environment of Pakistan, Pakistan Vet. J., 2008, 28(1): 9-12.9.

Maler, (2010). Bulletin of Agriculture Economics, Central Administration of Agriculture Economics, Ministry of Agriculture and Land Reclamation. Published data.

Marizok, K.M. (1998). A comparison between imported and locally-born Friesian cows in Egypt, J. Agric. Sci, Mansoura Uni .Egypt, 23:5861.

McDowell, R.E. (1985). Crossbreeding in tropical areas with emphasis on milk, health and fitness. J. Dairy Sci., 68: 2418-2435

Mohamed, A. A., M. A. El-Ashry and A. M. El-Serafy (1980). Reproductive performance of buffalo heifers bred at young age. Indian J. Anim. Sci., 50: 810.

Mostafa Abdel R. I. (2012). Water Buffalo for our next generation in Egypt and in the world, Animal Science, Series D, vol. LV CD-ROM ISSN 2285-5769, ISSN-L 2285-5750 Kafrelsheikh University.

Msanga, Y.N., M.J. Bryant and L. Zylstra (2000). Effect of environmental factors and of the proportion of Holstein blood on the milk yield and lactation length of crossbred dairy cattle on smallholder farms in north-east Tanzania. Trop. Anim. Health Prod. 2000; 32(1), 23-31.

Mukasa-Mugerwa, E. (1989). A review of reproductive performance of female Bos Indicus (Zebu) cattle. Addis Ababa, Ethiopia: International Livestock Centre for Africa.

NRC (1989). National Research Council. Nutrient requirements of dairy cattle.National Academy of Science, Washington, D.C. USA.

Oliveria, F. M. D. E. (1975). Some factors effecting milk production of HolsteinFriesian herd.Thesis, Universidade Fedral de Minas garais Brazil.

Paisha, T.N. (2007). Comparison between bovine and buffalo milk yield in Pakistan Italian Journal of Animal Science, Volume 6, 2007.

Patrick, M., W. Raphael and K. Paul (2015). Livestock herd structures and dynamics in Garissa County, Pastoralism: Research, Policy and Practice20155:26 https://doi.org/10.1186/s13570-0150045-6C .

Pereira, B.M. and M. Jayasuriya (2008). The dairy industry in Sri Lanka: current status and future directions for a greater role in national development. Journal of National Science Foundation Sri Lanka, 36: 115-126.

Qureshi, M. S., G. M. Safi, J. Dhanani and I. Kaka (1999). Reproductive performance of dairy buffaloes in Northern hilly areas of Pakistan. Buffalo Bulletin. 15(3): 391-396.

Radwan, M. A., S. Abdelghany and V. Alary (2016): Characterization of the diversity of dairy farming systems and milk marketing strategies around greater Cairo (Egypt) . Journal homepage: http://www.journalijar.com International Journal of Advanced Research Article.

Sattar, A., R.H. Mirza, A.A.K. Niazi and M. Latif (2005). Productive and reproductive performance of Holstein- 
Friesian cows in Pakistan. Pakistan Veterinary Journal, 25: 75-81.

Shalaby, N.A. (2001). Sire evaluation for lifetime milk yield and longivity traits. Ph.D. Thesis, Faculty of Agriculty Mansoura University, Egypt.

Smith, J.W., L.O. Ely and A.M. Chapa (2000). Effect of region, herd size, and milk production on reasons cows leave the herd. Journal of Dairy Science 83 2980-2987

Sol, J., J. Stelwagen and A.A. Dijkhuizen (1984). A 3 year herd health and management program on 30 Dutch dairy farms $0 \cdot 2$. Culling strategy and losses caused by forced replacement of dairy cows. Veterinary Quarterly 6 149-157

Soliman, I. (2004). Feasibility of Buffalo Production in Egyptian Economy through A Planning Model," Conference Papers 210363, Zagazig University, Department of Agricultural Economics.

SPSS (2015). Statistical Package for Social Sciences, Version 20, (SPSS) INC, Chicaco, USA

Stewart, P. G. (2015). Dairying in Kwazulu -Natal Dairy Herd Structure I Dairy Herd Dynamics. Department of agriculture and rural development Cedara Agricultural Development Institute, province of Kwazulu-Natal.

Tabana, A. S. (2000). Development of a Decision Support System for Individual Dairy Farms in Mixed Irrigated Farming Systems in the Nile Delta. Ph.D. Thesis Wageningen University, Wageningen, The Netherlands.

Tadesse, M., J. Thiengtham and $S$. Prasanpanich (2010). Productive and reproductive performance of Holstein Friesian dairy cows in Ethiopia. Livestock Research for Rural Development, 22 (2).

Tonhati, H., M.F.C. Muñoz and A.L.F. Lima (2004). Estimates of correction factors for lactation length and genetic parameters for milk yield in buffaloes. Arq Bras Med Vet Zootec 56:251-257.

USDA, United States Department of Agriculture (2014). Livestock and Products " USDA GAIN: Egypt Livestock and Products Annual 2014. 12 September 2014S\&D) table is comprised of roughly half cattle and half buffalo.

Usman, G., S. Ahmed and Y. Wang (2012). Performance traits study of Holstein Friesian Cattle under subtropical condition. The Journal of Animal and Plant Sciences, 22(2 Suppl.): 2012, Page: 92-95 ISSN: 1018-7081.

Yousaf, H., R. Majed and Irfan Shahzad (2011). Study on performance analysis of Holstein Frisian cattle under intensive management at government dairy farm, Pishin, Balochistan. Animal Biology \& Animal Husbandry International Journal of the Bioflux Society ABAH Bioflux, 2011, Volume 3, Issue 1. http://www.abah.bioflux.com.ro

Zaabal, M. M. and W.M. Ahmed (2001). Monitoring of Some Reproductive Parameters in Local Egyptian Friesian Cows with Emphasis on the Use of Immunogenetic Analysis for Evaluation of Fertility. Global Journal of Molecular Sciences 3 (1): 21-26, 2001 ISSN 1990-9241 (C) IDOSI Publications.

Zahid, S. S., M. T. Mohammad and A. Q. Muhammad (2011). Performance Analysis of Holstein-Friesian Cattle in Intensive Management at Dairy Farm Quetta, Balochistan, Quetta, Pakistan. Pak. j. life soc. Sci. (2011), 9(2): 128133.

Zaied, A.A. (2011). The effect of local environment on reproductive and productive traits of exotic breeds in Arab World. Arab Organization of Agricultural Development. Paper in the International forum of evaluation of exotic cattle breed and their adaptation to the environment in Arab World. 


\section{دراسة مقارنة بين أنظمة إنتاج الألبان المختلفة في مصر

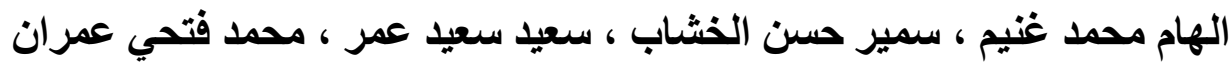

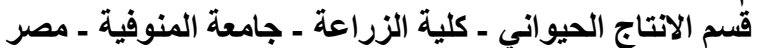

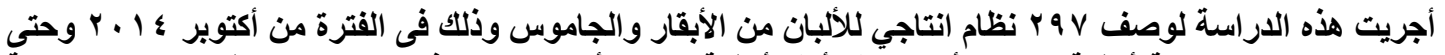

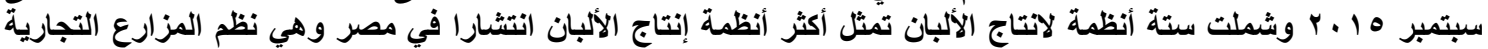

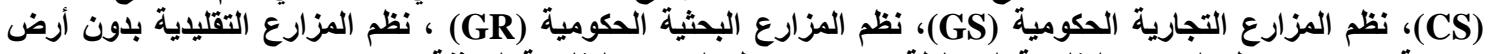

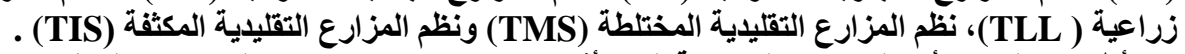

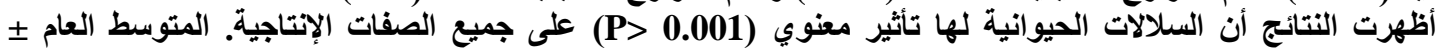

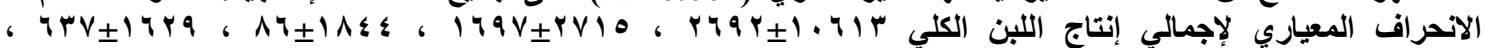

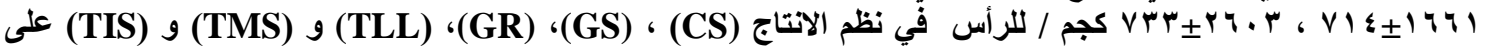

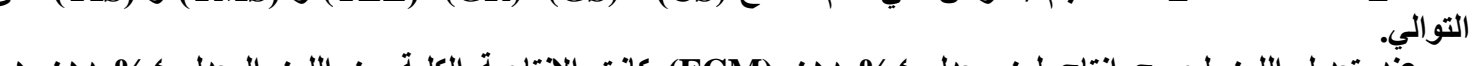

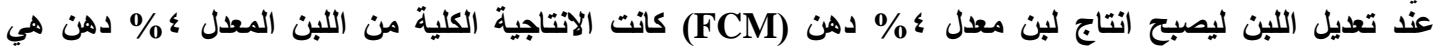

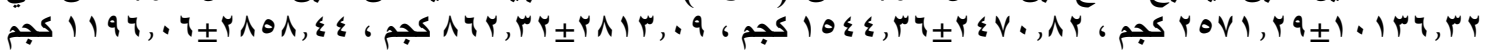

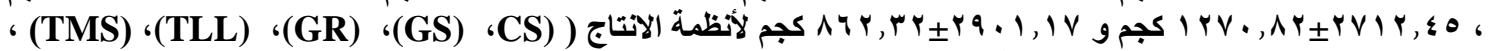

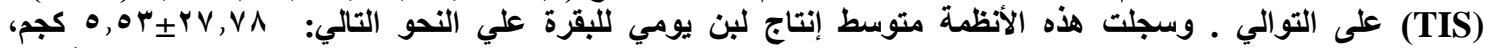

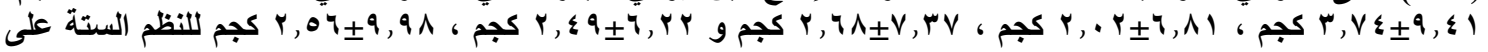

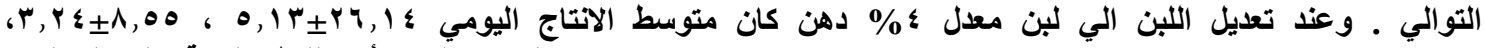

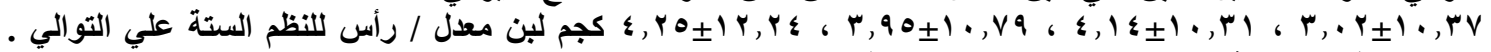
ارتبطت هذه الاتتاجية بطول موسم حليب

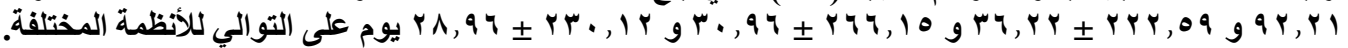

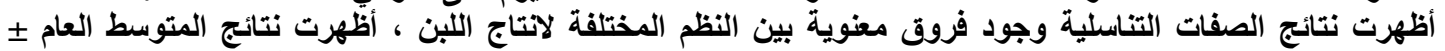

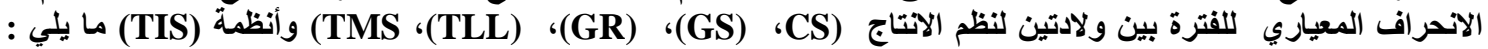

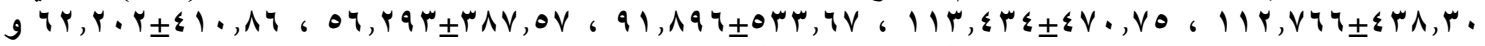

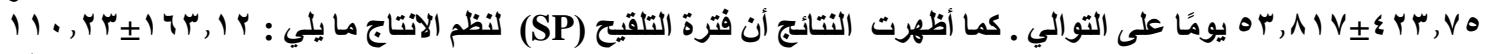
،

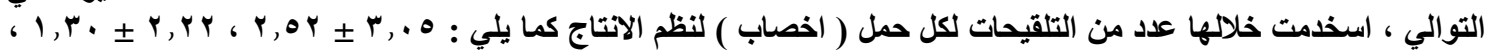
الو 1 , الكلمات المفتاحية: أنظمة إنتاج الألبان ، التوصيف مثئ ، الصفات الانتاجية والتناسلية

أسماء السادة المحكمين

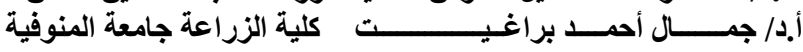

